\title{
A progressão do conhecimento histórico na educação básica: dilemas da transição entre os níveis fundamental e médio
}

\author{
Flávia Eloisa Caimi*
}

Sandra Regina Ferreira de Oliveira**

\begin{abstract}
Resumo
O presente estudo parte do pressuposto de que a organização do trabalho escolar, neste caso, a que diz respeito ao ensino-aprendizagem do conhecimento histórico, implica realizar articulaçóes qualificadas entre a epistemologia da ciência de referência e o desenvolvimento das capacidades e habilidades de pensamento dos alunos. Ao considerar que na tarefa de ensinar há que reconhecer tanto a aquisição de conteúdos quanto as capacidades de pensar/aprender, o esforço para garantir a progressão racional do ensino com vistas à complexificaçáo da aprendizagem ganha especial relevância. Na investigação foram elencadas algumas especificidades relacionadas aos processos de ensinoaprendizagem da História no ensino fundamental e médio, tanto do ponto de vista da organizaçáo curricular dos conteúdos quanto das capacidades cognitivas do sujeito que aprende, considerando a progressão da complexidade dos conteúdos, conceitos, noçóes e metodologias. Após revisitar a literatura pertinente e alguns documentos curriculares, a análise ancora-se em duas coleçóes didáticas de História, uma de cada segmento, no intuito de identificar que decisôes são tomadas na organização da proposta histórica e pedagógica e analisar como é entendida/efetivada a progressáo do conhecimento histórico entre elas. Os resultados preliminares apontam que são escassas as referências à progressão do conhecimento histórico nos materiais analisados, o que se traduz na dificuldade de apontar o que se almeja como avanços qualitativos para a última etapa da educação básica. De tal forma, o pouco avanço constatado nos documentos quanto aos diferentes potenciais de aprendizagem entre os dois segmentos, não é explicitamente considerado para a composiçáo do livro didático.

Palavras-chave: Aprendizagem. Currículo. Livro Didático.
\end{abstract}

\footnotetext{
* Doutora em Educaçáo pela Universidade Federal do Rio Grande do Sul (UFRGS). Professora do Curso de História e da Pós-Graduação em Educação na Universidade de Passo Fundo (UPF/RS). ** Doutora em Educação pela Universidade Estadual de Campinas (UNICAMP). Professora do Curso de Pedagogia e do Programa de Pós-Graduação em Educação na Universidade Estadual de Londrina (UEL/PR).
} 
Como as pessoas aprendem? Esta é, segundo o nosso ponto de vista, uma das mais relevantes interrogações dos professores que se propóem a trabalhar para que seus alunos efetivamente aprendam. Fazer o outro aprender pode ser bem mais complexo do que ensinar, assim como é complexo aos professores responder a essa pergunta aparentemente simples, para a qual muitos de nós não temos resposta pronta. Num esforço de buscar tais respostas entre os professores, certamente encontraríamos posições muito distintas, revelando diferentes e divergentes compreensóes do que seja a aprendizagem e, por conseguinte, do que seja o ensino.

Nas últimas décadas localizamos, no domínio acadêmico, três vertentes que tentam responder às questôes sobre a aprendizagem histórica, a saber: epistemologia da história, psicologia cognitiva e cultura escolar. Esses três campos vêm disputando territórios, contrapondo posiçóes e argumentos, no esforço de compreender/explicar os processos de ensinar-aprender História na escola. Neste percurso, ora se aproximaram, ora se afastaram; ora dialogaram, ora negaram um ao outro. Muitas vezes se acreditou que apenas um destes vieses daria conta das interrogaçôes sobre o ensino e aprendizagem histórica. A posição que defendemos no presente estudo propóe que o avanço das discussóes neste domínio nấo pode mais prescindir do diálogo entre a ciência de referência, a psicologia cognitiva e a cultura escolar, por mais difíceis que sejam os deslocamentos epistemológicos e metodológicos, ou por mais desconfortáveis que possam parecer as pesquisas em zonas de fronteira disciplinar.

Num contexto de sociedades complexas e plurais como o que ora vivemos, imersos num mundo que se movimenta em vertiginosas transformaçóes, prestar atenção às demandas dos processos de ensino-aprendizagem é uma exigência fundamental para se prover aos alunos "os meios cognitivos e instrumentais de compreender e lidar com os desafios postos por essa realidade" (LIBÂNEO, 2011, p. 189). Tais objetivos, para o autor, dizem respeito ao desenvolvimento da razão crítica, à capacidade de refletir e intervir na realidade, contando com sólida formaçâo cultural e científica; ao domínio de competências cognitivas que favoreçam o 'aprender a pensar', dentre outros. Para se chegar a esses objetivos, há que se considerar tanto a aquisição de conhecimentos/conteúdos quanto a mobilizaçáo das capacidades de pensar, tomando-os como processos indissociáveis e articulados entre si (LIBÂNEO, 2011).

Circunscrevendo os processos de ensino-aprendizagem no âmbito da organização do trabalho escolar, a partir de um ponto de vista didático, Thurler 
e Maulini (2012, p. 23) defendem que, em qualquer área ou disciplina em que se atue, é preciso considerar "as ligaçóes entre a epistemologia de referência e uma organizaçấo do trabalho que garanta a progressão racional do ensino".

Avançar na discussão de questôes dessa natureza, que dizem respeito à necessária gradualização dos conhecimentos escolares e à progressão lógica do processo de ensino-aprendizagem, exige que busquemos respostas para algumas indagaçôes, como, por exemplo: 1) Com quais habilidades de pensamento histórico se espera que os jovens cheguem ao ensino médio? 2) Com base nisso, quais avanços qualitativos se almeja desenvolver nesta última etapa da educação básica? 3) As propostas de História contempladas nas atuais políticas educacionais públicas levam em conta as expectativas de conteúdos e as diferenças potenciais de aprendizagem entre os dois segmentos? 4) Os livros didáticos de História destinados aos anos finais do ensino fundamental e ao ensino médio, disponíveis atualmente no mercado, apresentam distinçôes significativas quanto ao aprofundamento dos conteúdos, à construção de conceitos e noções, à proposta curricular, aos aportes metodológicos, dentre outros?

Considerando a amplitude dessas questôes, nos limites deste artigo trataremos especificamente das demandas de progressão que se colocam nas situações de transição do nível fundamental para o médio, tomando como campos de análise alguns documentos orientadores da organização de conteúdos da História escolar e o livro didático, entendido aqui como um locus privilegiado, atualmente, de ordenamento curricular do conhecimento histórico.

\section{As Diretrizes Curriculares: qual currículo? Qual progressão?}

Para alguns autores, dentre os quais se podem mencionar Sacristán (1996), Otano (1999), Moehlecke (2012) e Sanchéz (2013), a ruptura mais radical dentro do sistema de educação básica é a que separa os níveis fundamental e médio, especialmente pelas profundas transformaçōes (biológicas, psicológicas, culturais) que os estudantes vivem nessa fase das suas vidas, marcada, em geral, pela transição da infância para a adolescência. Sánchez (2013, p. 370) chega a afirmar que "a educação secundária é a etapa mais complexa do sistema educacional em todos os países da Europa". Estes mesmos autores apontam a falta de investigaçóes e estudos acerca das transiçóes educativas, situação que dificulta a ação orientadora e a elaboração de propostas efetivas no momento em que se produz a transição. 
Avaliar o peso das transiçôes educativas no processo de escolarização dos jovens implica direcionar o olhar para a noção de currículo como um poder regulador e unificador necessário, para alguns, "um mal necessário", na medida em que os sistemas escolares se converteram em fenômeno de massa, sob os princípios da "educação para todos". A potencialidade reguladora e unificadora do currículo se dá em diversos âmbitos, de acordo com Sacristán (2013): na ordenação dos conteúdos a ensinar em forma de matérias, disciplinas, territórios disciplinares, especialidades; no conceito de classe ou turma para agrupar e classificar um grande número de alunos por idades, sob os cuidados de um só professor; na distinçáo de graus, séries ou níveis, para viabilizar a sequência e a complexidade gradual nas transiçóes; na determinaçáo do tempo escolar, de modo a possibilitar o desenvolvimento e a progressáo dos sujeitos na escolaridade e cumprir coletivamente um mesmo calendário letivo; no estabelecimento de métodos de ensino, para que os conteúdos sejam tratados sob uma lógica, com começo, meio e fim.

Em síntese, diz Sacristán (2013, p. 19), “o currículo proporciona uma ordem por meio da regulação do conteúdo da aprendizagem e ensino na escolarização moderna, uma construçáo útil para organizar aquilo do qual deve se ocupar a escolarizaçáo e aquilo que deverá ser aprendido", formando todo o dispositivo da normalizaçáo escolar. Isso define a escola como agência autorizada pelo Estado, a quem se confia a tarefa de formar as futuras geraçóes, transmitindo-lhes o chamado patrimônio cultural da humanidade, ou, ao menos, aquilo que cada sociedade, em cada época, convenciona que deva ser o "conhecimento para todos".

No Brasil, toda abordagem que se convencione "para todos" denota cuidados. Somos um país plural, marcado pela diversidade e que, politicamente, nas últimas décadas, tem investido de forma clara na importância de assumir essa pluralidade. Sendo a escola uma instituição sob a responsabilidade do Estado, a opção pela pluralidade não é tarefa fácil e os documentos nacionais expressam o esforço de encontrar um ponto de equilíbrio, se é que ele existe, entre a indicaçáo de parâmetros mínimos para todos e a garantia da diversidade que nos caracteriza.

Em 1996, quando da aprovação da Lei no 9394 (BRASIL, 1996), que estabelece a Lei de Diretrizes e Bases da Educação Nacional (LDB), garante-se em forma de Lei o pluralismo de ideias e de concepçôes pedagógicas (Art. 3º, $\$$ III) e delega-se à União a incumbência de coordenar a política nacional de educação de forma a articular os diferentes níveis e sistemas (Art. $8^{\circ}, 1^{\circ}$ ). Institui- 
se o regime de colaboração entre a União, Distrito Federal, estados e municípios quanto à organização dos sistemas de ensino (Art. $8^{\circ}$ ) e o estabelecimento de "competências e diretrizes para a educação infantil, o ensino fundamental e o ensino médio, que nortearão os currículos e seus conteúdos mínimos, de modo a assegurar formação básica comum" (Art. 9º $\$$ IV). Também foi garantida na forma da Lei que os estabelecimentos de ensino elaborem e executem sua proposta pedagógica (Art. 12. $\$ \mathrm{I}$ ), desde que de forma consoante as normas comuns e as do seu sistema de ensino, e aos professores a incumbência de "elaborar e cumprir plano de trabalho, segundo a proposta pedagógica do estabelecimento de ensino" (Art. 13. \$ II). Especificamente sobre currículos, rege o Artigo 26 que estes devem ter uma base nacional comum, acrescentada de uma parte diversificada, para atender as características regionais.

A autonomia dos estados, municípios, escolas e professores quanto à elaboração das propostas curriculares e a eficiência deste modelo quanto à construção e efetivação de um projeto educacional de qualidade, não é consenso entre os que se dedicam à educação. Há os que defendem e valorizam tal abertura por compreenderem que a mesma garante a possibilidade de atender as diversidades do país e há os que entendem que a Lei é omissa porque não assume o papel do Estado enquanto gestor do projeto nacional para a educação.

As definições sobre a base nacional comum e a parte diversificada encontram-se nas Diretrizes Curriculares Nacionais Gerais da Educaçăo Básica $(\mathrm{DCN})$ que, dentre outras questóes, intentam assegurar "a integração curricular das três etapas sequentes desse nível da escolarização, essencialmente para compor um todo orgânico" (BRASIL, 2013a, p. 8). As propostas curriculares e os livros didáticos, que são em sua maioria destinados a estudantes de todos os estados brasileiros, devem atender ao constante neste documento.

Por compreender a educação básica como um todo indissociável, estabelece-se nas DCN o compromisso de assumir as fases de transição como momentos importantes da vida escolar. Após dissertar sobre aspectos referentes à transição da educação infantil para os anos iniciais do ensino fundamental e, deste para os anos finais, o destaque recai na transição do ensino fundamental para o médio que, segundo o preconizado no documento:

[...] apresenta contornos bastante diferentes dos anteriormente referidos, uma vez que, ao ingressarem no Ensino Médio, os jovens já trazem maior experiência 
com o ambiente escolar e suas rotinas; além disso, a dependência dos adolescentes em relação às suas famílias é quantitativamente menor e qualitativamente diferente. Mas, certamente, isso não significa que não se criem tensôes, que derivam, principalmente, das novas expectativas familiares e sociais que envolvem o jovem. Tais expectativas giram em torno de três variáveis principais, conforme o estrato sociocultural em que se produzem: a) os "conflitos da adolescência"; b) a maior ou menor aproximação ao mundo do trabalho; c) a crescente aproximação aos rituais da passagem da Educação Básica para a Educação Superior. (BRASIL, 2013a, p. 20).

Sobre a organização dos conteúdos, após explanar sobre o conceito de matriz curricular em contraposição ao conceito de grade curricular, indicase que composiçóes diversas são possíveis quanto à "forma de gestão do conhecimento pelos sujeitos que dão vida ao cotidiano escolar" (BRASIL, 2013a, p. 30). Paralelamente ao anúncio da diversidade, e por considerar a abordagem interdisciplinar em relação aos conhecimentos a serem ensinados na escola, a proposta curricular organizada por eixos temáticos é sugerida por possibilitar o trato com os conteúdos a partir de diferentes enfoques, restringir a dispersão temática, facilitar a "problematização e o encadeamento lógico dos conteúdos e a abordagem selecionada para a análise e/ou descrição dos temas" (BRASIL, 2013a, p. 30).

Verificaremos posteriormente que a forma como os conteúdos estão apresentados nos livros didáticos se distanciam sobremaneira do preconizado nas DCN, assim como se distanciam das práticas desenvolvidas nas escolas e da formação recebida pelos professores. A proposta de matriz curricular divulgada no documento e que pressupóe outras composiçóes no que se refere à organização curricular não se instituiu na cultura escolar. O que permanece, embora revestido por outras nomenclaturas, de forma geral, é uma proposta curricular organizada, em sua essência, a partir do que outrora se denominou "grade curricular".

A partir dessas indicações importantes sobre a educação básica e sobre as possibilidades de outras composiçóes para as propostas curriculares, apresentamos o cotejamento entre o estabelecido nas DCN para o ensino fundamental de nove anos e o ensino médio. Priorizamos tratar aspectos como as 
definiçóes quanto à base nacional comum eà base diversificada; os componentes curriculares; as orientaçôes específicas sobre o ensino da História; e, por fim, à articulação e ou progressão do conhecimento.

Quadro 1 - Comparativo das Diretrizes Curriculares Nacionais do Ensino Fundamental e Médio

\begin{tabular}{|c|c|}
\hline $\begin{array}{l}\text { ENSINO FUNDAMENTAL DE } \\
\text { NOVE ANOS Resoluçáo CNE/CEB } \\
\text { 7/2010, publicada no Diário Oficial } \\
\text { da Uniáo em } 15 \text { de dezembro de } \\
2010 .\end{array}$ & $\begin{array}{c}\text { ENSINO MEDIO } \\
\text { Resoluçáo CNE/CEB 2/2012. Diário } \\
\text { Oficial da União, Brasília, } 31 \text { de } \\
\text { janeiro de 2012. }\end{array}$ \\
\hline \multicolumn{2}{|c|}{ Base nacional comum } \\
\hline $\begin{array}{l}\text { Art. 13: Os conteúdos a que se } \\
\text { refere o art. } 12 \text { são constituídos por } \\
\text { componentes curriculares que, por } \\
\text { sua vez, se articulam com as áreas de } \\
\text { conhecimento, a saber: Linguagens, } \\
\text { Matemática, } \\
\text { Ciências da Natureza e Ciências } \\
\text { Humanas. As áreas de conhecimento } \\
\text { favorecem a comunicaçáo } \\
\text { entre diferentes conhecimentos } \\
\text { sistematizados e entre estes e outros } \\
\text { saberes, maspermitem que os referenciais } \\
\text { próprios de cada componente curricular } \\
\text { sejam preservados. } \\
\text { Art. } 14 \text { : O currículo da base nacional } \\
\text { comum do Ensino Fundamental deve } \\
\text { abranger, obrigatoriamente, conforme } \\
\text { o art. } 26 \text { da Lei no } 9.394 / 96 \text {, o estudo } \\
\text { da Língua Portuguesa e da Matemática, } \\
\text { o conhecimento do mundo físico e } \\
\text { natural e da realidade social e política, } \\
\text { especialmente a do Brasil, bem como o } \\
\text { ensino da Arte, a Educação Física e o } \\
\text { Ensino Religioso. }\end{array}$ & $\begin{array}{l}\text { Art. } 7^{\circ} \text { : A organização curricular do } \\
\text { Ensino Médio tem uma base nacional } \\
\text { comum e uma parte diversificada que } \\
\text { náo devem constituir blocos distintos, } \\
\text { mas um todo integrado, de modo } \\
\text { a garantir tanto conhecimentos e } \\
\text { saberes comuns necessários a todos } \\
\text { os estudantes, quanto uma formação } \\
\text { que considere a diversidade e as } \\
\text { características locais e especificidades } \\
\text { regionais. } \\
\text { Art. 8o: O currículo é organizado em } \\
\text { áreas de conhecimento, a saber: } \\
\text { I - Linguagens; } \\
\text { II - Matemática; } \\
\text { III - Ciências da Natureza; } \\
\text { IV - Ciências Humanas. }\end{array}$ \\
\hline
\end{tabular}




\begin{tabular}{|c|c|}
\hline \multicolumn{2}{|c|}{ Sobre base diversificada } \\
\hline $\begin{array}{l}\text { Art. } 11 \$ 3^{\circ} \text { : Os conteúdos curriculares } \\
\text { que compóem a parte diversificada do } \\
\text { currículo seráo definidos pelos sistemas } \\
\text { de ensino e pelas escolas, de modo a } \\
\text { complementar e enriquecer o currículo, } \\
\text { assegurando a contextualizaçáo dos } \\
\text { conhecimentos escolares em face das } \\
\text { diferentes realidades. }\end{array}$ & $\begin{array}{l}\text { Art. 11. Outros componentes } \\
\text { curriculares, a critério dos sistemas } \\
\text { de ensino e das unidades escolares e } \\
\text { definidos em seus projetos político- } \\
\text { pedagógicos, podem ser incluídos no } \\
\text { currículo, sendo tratados ou como } \\
\text { disciplina ou com outro formato, } \\
\text { preferencialmente, de forma transversal } \\
\text { e integradora. }\end{array}$ \\
\hline \multicolumn{2}{|c|}{ Sobre componentes curriculares } \\
\hline $\begin{array}{l}\text { Art. 15. Os componentes curriculares } \\
\text { obrigatórios do Ensino Fundamental } \\
\text { serão assim organizados } \\
\text { em relação às áreas de conhecimento: } \\
\text { I - Linguagens: } \\
\text { a) Língua Portuguesa; } \\
\text { b) Língua Materna, para populaçôes } \\
\text { indígenas; } \\
\text { c) Língua Estrangeira moderna; } \\
\text { d) Arte; e } \\
\text { e) Educação Física; } \\
\text { II - Matemática; } \\
\text { III - Ciências da Natureza; } \\
\text { IV - Ciências Humanas: } \\
\text { a) História; } \\
\text { b) Geografia; } \\
\text { V - Ensino Religioso. }\end{array}$ & $\begin{array}{l}\text { Art. } 9^{0} \text { - Parágrafo único. Em termos } \\
\text { operacionais, os componentes } \\
\text { curriculares obrigatórios decorrentes } \\
\text { da LDB que integram as áreas de } \\
\text { conhecimento são os referentes a: } \\
\text { I - Linguagens: } \\
\text { a) Língua Portuguesa; } \\
\text { b) Língua Materna, para populaçôes } \\
\text { indígenas; } \\
\text { c) Língua Estrangeira moderna; } \\
\text { d) Arte, em suas diferentes linguagens: } \\
\text { cênicas, plásticas e, obrigatoriamente, a } \\
\text { musical; } \\
\text { e) Educação Física. } \\
\text { II - Matemática. } \\
\text { III - Ciências da Natureza: } \\
\text { a) Biologia; } \\
\text { b) Física; } \\
\text { c) Química. } \\
\text { IV - Ciências Humanas: } \\
\text { a) História; } \\
\text { b) Geografia; } \\
\text { c) Filosofia; } \\
\text { d) Sociologia. }\end{array}$ \\
\hline
\end{tabular}




\begin{tabular}{|c|c|}
\hline \multicolumn{2}{|c|}{ Sobre referências específicas do ensino de História } \\
\hline 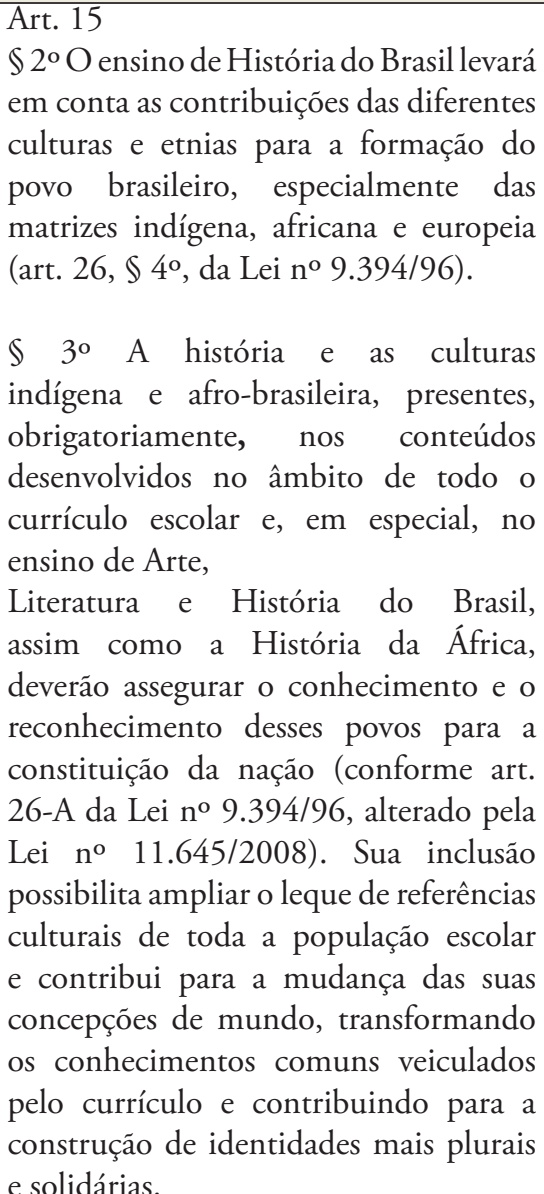 & $\begin{array}{l}\text { Art. } 9^{\circ} \\
\text { c) o ensino da História do Brasil, que } \\
\text { leva em conta as contribuiçốes das } \\
\text { diferentes culturas } \\
\text { e etnias para a formação do povo } \\
\text { brasileiro, especialmente das matrizes } \\
\text { indígena, africana } \\
\text { e europeia; } \\
\text { d) o estudo da História e Cultura Afro- } \\
\text { Brasileira e Indígena, no âmbito de } \\
\text { todo o currículo } \\
\text { escolar, em especial nas áreas de } \\
\text { Educação Artística e de Literatura e } \\
\text { História brasileiras; } \\
\text { Art. 12. O currículo do Ensino Médio } \\
\text { deve: } \\
\text { I - garantir açóes que promovam: } \\
\text { b) o processo histórico de } \\
\text { transformação da sociedade e da } \\
\text { cultura; }\end{array}$ \\
\hline
\end{tabular}




\begin{tabular}{|c|c|}
\hline \multicolumn{2}{|c|}{ Detalhamentos quanto à organizaçáo dos conteúdos } \\
\hline Art. 24 & Art. 14 \\
\hline$\$ 2^{\circ}$ Constituem exemplos de & VIII - os componentes curriculares \\
\hline possibilidades de integração do & que integram as áre \\
\hline currículo, entre outros, as propostas & podem ser tratados \\
\hline curriculares ordenadas em torno de & ou como disciplinas, sempre de forma \\
\hline grandes eixos articuladores, projetos & integrada, ou como unidades de \\
\hline interdisciplinares & estudos, módulos, \\
\hline com base em temas geradores & atividades, práticas e projetos \\
\hline formulados a partir de questóes da & contextualizados e interdisciplinares ou \\
\hline comunidade e articulados aos & diversamente a \\
\hline componentes curriculares e às áreas & de saberes, desenvolvimento transversal \\
\hline $\begin{array}{l}\text { de conhecimento, currículos em rede, } \\
\text { propostas ordenadas em torno de }\end{array}$ & $\begin{array}{l}\text { de temas ou outras formas de } \\
\text { organizacão; }\end{array}$ \\
\hline conceitos-chave ou conceitos nucleares & XII - formas diversificadas de \\
\hline que permitam trabalhar as questóes & itinerários podem ser organizadas, \\
\hline cognitivas e as questôes culturais numa & desde que garantida a simultaneidade \\
\hline perspectiva transversal, e projetos de & entre as dimensóes do trabalho, da \\
\hline trabalho com diversas acepçóes. & $\begin{array}{l}\text { ciência, da tecnologia e da cultura, e } \\
\text { definidas }\end{array}$ \\
\hline$\$ 3^{\circ}$ Os projetos propostos pela escola, & pelo projeto político-pedagógico, \\
\hline comunidade, redes e sistemas de ensino & atendendo necessidades, anseios e \\
\hline $\begin{array}{l}\text { serão articulados ao desenvolvimento } \\
\text { dos componentes curriculares e às }\end{array}$ & $\begin{array}{l}\text { aspiraçóes dos sujeitos e a } \\
\text { realidade da escola e do seu meio; }\end{array}$ \\
\hline áreas de conhecimento, observadas & XIII - a interdisciplinaridade e a \\
\hline as disposiçóes contidas nas Diretrizes & contextualização devem assegurar a \\
\hline Curriculares Nacionais Gerais para a & transversalidade do conhecimento de \\
\hline Educação Básica (Resolução CNE/ & diferentes componentes curriculares, \\
\hline CEB no 4/2010, art. 17) e nos termos & propiciando a interlocução entre os \\
\hline do Parecer que dá base à presente & saberes e os diferentes campos do \\
\hline $\begin{array}{l}\text { Resoluc } \\
\text { Gonte: Di }\end{array}$ & RASIL, 2 \\
\hline
\end{tabular}

A análise comparada do quadro 1 possibilita algumas inferências. A organização da base nacional por áreas de conhecimento é indicada para os dois níveis de ensino. Tal indicaçáo é relativizada ao se resguardar o direito dos sistemas de ensino e das unidades escolares constituírem outras formas de organizaçáo dos conteúdos para o ensino fundamental e dos componentes curriculares, para o ensino médio. Sobre o que venha a ser "componentes curriculares", os pareceristas do documento ressaltam em nota específica que "[...] a LDB utiliza 
diversidade de termos correlatos, empregando concorrentemente e sem rigor conceitual os termos disciplina, componente curricular, estudo, conhecimento, ensino, matéria, conteúdo curricular"(BRASIL, 2013a, p. 186, grifo nosso).

O ensino da História é referendado no documento no que diz respeito ao trato com a História do Brasil e à obrigatoriedade do prescrito na Lei 11.645/2008, que versa sobre a História da África e a História e Cultura AfroBrasileira e Indígena (BRASIL, 2008). Ainda que no documento referente ao ensino médio conste que os componentes curriculares possam ser tratados como disciplinas, é explícita a indicação para romper com a lógica disciplinar no trato com os conhecimentos na escola. Empregam-se termos que remetem a diferentes conceitos no que concerne à forma de trabalhar com os conteúdos: eixos articuladores; projetos interdisciplinares; currículo em rede; conceitos-chaves; projetos contextualizadores; desenvolvimento transversal.

O cotejamento entre o postulado nas Diretrizes Nacionais para o ensino fundamental e para o ensino médio indica que as orientaçôes quanto à articulação ou progressão do conhecimento entre os níveis de ensino citados não é temática a receber destaque. Aqui e acolá se localizam referências ao assunto, mas o que se tem, efetivamente, são documentos que abordam, separadamente, cada nível da educação básica. Como se trata de um documento para o país que, como já dito, é marcado pela diversidade, não se adentra em especificidades.

A pesquisa prossegue então com a análise das Diretrizes Curriculares da Educação Básica-História (PARANÁ, 2008), do estado do Paraná. Este documento foi colocado em circulação no ano de 2008, portanto, é anterior ao documento do ensino médio (aprovado em 2011) e do ensino fundamental (aprovado em 2010).

Na proposta curricular do estado do Paraná a ênfase recai nos conteúdos estruturantes, entendidos no documento como "conhecimentos de grande amplitude que identificam e organizam os campos de estudos de uma disciplina escolar, considerados fundamentais para a compreensão de seu objeto de estudo e ensino" (PARANÁ, 2008, p. 63). A partir dos conteúdos estruturantes organizam-se os conteúdos básicos que são "compostos tanto pelos assuntos mais estáveis e permanentes da disciplina quanto pelos que se apresentam em função do movimento histórico e das atuais relaçôes sociais" (PARANÁ, 2008, p. 26).

Quanto às especificidades do ensino e da aprendizagem da História encontramos no documento as referências que constam no quadro 2 : 
Quadro 2 - Especificidades do ensino fundamental e médio nas DCEB/Paraná - História

\begin{tabular}{|c|c|}
\hline Ensino Fundamental & Ensino Médio \\
\hline \multicolumn{2}{|c|}{ Sobre a finalidade do ensino de História } \\
\hline $\begin{array}{l}\text { Para os anos finais do Ensino } \\
\text { Fundamental propóe-se, nestas } \\
\text { Diretrizes, que os conteúdos temáticos } \\
\text { priorizem as histórias locais e do Brasil, } \\
\text { estabelecendo-se relaçóes e comparaçóes } \\
\text { com a história mundial. (p. 68). }\end{array}$ & $\begin{array}{l}\text { Para o Ensino Médio, a proposta é um } \\
\text { ensino por temas históricos, ou seja, os } \\
\text { conteúdos (básicos e específicos) teráo } \\
\text { como finalidade a discussão e a busca } \\
\text { de solução para um tema/problema } \\
\text { previamente proposto. (p. } 68 \text { ). }\end{array}$ \\
\hline
\end{tabular}

\section{Sobre conteúdos}

No Ensino Fundamental, os Conteúdos Para o Ensino Médio, a metodologia Estruturantes - Relaçóes de Trabalho, proposta por estas Diretrizes Curriculares Relaçôes de Poder e Relaçôes Culturais está relacionada à História Temática. -, tomados em conjunto, articulam os Os conteúdos básicos/temas históricos conteúdos básicos e específicos a partir das selecionados para o ensino devem histórias locais e do Brasil e suas relaçóes articular-se aos Conteúdos Estruturantes ou analogias com a História Geral, e propostos nestas Diretrizes. Tomá-los permitem acesso ao conhecimento de como ponto de partida é uma forma múltiplas açóes humanas no tempo e no de responder às críticas a respeito da espaço. Por meio do processo pedagógico, impossibilidade de ensinar "toda a história busca-se construir uma consciência da humanidade". A organização do histórica que possibilite compreender a trabalho pedagógico por meio de temas realidade contemporânea e as implicaçóes históricos possibilita ao professor ampliar do passado em sua constituição. (p. 74). a percepção dos estudantes sobre um determinado contexto histórico, sua ação e relaçōes de distinção entre passado e presente. (p. 76).

Para os anos finais do Ensino Para o Ensino Médio, reforça-se a ideia Fundamental a escolha dos recortes de que os conteúdos básicos são os temáticos que organizam os conteúdos temas históricos. Nessas Diretrizes, essa básicos se deve à opçáo política e teórico- identificação se justifica pela opção teóricometodológica de romper com a narrativa metodológica, pela história temática. Os histórica tradicional, linear, eurocêntrica, temas históricos estão necessariamente homogeneizadora e totalizante da articulados aos conteúdos estruturantes. A divisão quadripartite (Antiga, Medieval, especificidade, nesse nível de ensino, está Moderna e Contemporânea). (p. 88). $\quad$ na formação de uma maior complexidade conceitual na explicação e interpretação históricas dos conteúdos específicos.

Fonte: Diretrizes Curriculares da Educação Básica (PARANA, 2008). 
Assume-se a opção por organizar os conteúdos para o ensino fundamental a partir de recortes temáticos, abarcando a história local e do Brasil trabalhada na relação com a história mundial. Para o ensino médio, indica-se a abordagem dos conteúdos a partir do viés da História Temática e da busca de soluçôes para um tema/problema proposto. A impossibilidade de se trabalhar com "toda a história da humanidade" é explicitamente assumida e o recorte temático é indicado como caminho para um estudo mais ampliado de relaçóes entre o passado e o tempo presente.

Ao final do documento é apresentado um quadro com os conteúdos estruturantes e básicos para o ensino fundamental e médio. As relaçôes de trabalho, relaçôes de poder e relaçôes culturais são indicadas como conteúdo estruturante para os dois segmentos de ensino. É indicado no quadro 3 os conteúdos básicos para o ensino fundamental e médio.

Quadro 3 - Conteúdos básicos para o ensino fundamental e médio

\begin{tabular}{|c|c|}
\hline $\begin{array}{c}\text { Conteúdos básicos: ensino } \\
\text { fundamental }\end{array}$ & Conteúdos básicos: ensino médio \\
\hline $\begin{array}{l}\text { 60 ano: A experiência humana no tempo. } \\
\text { Os sujeitos e suas relaçóes com o outro } \\
\text { no tempo. As culturas locais e a cultura } \\
\text { comum. } \\
7^{\mathbf{0}} \text { ano: As relaçóes de propriedade. A } \\
\text { constituição histórica do mundo do } \\
\text { campo e do mundo da cidade. As relaçóes } \\
\text { entre o campo e a cidade. Conflitos e } \\
\text { resistências e produçáo cultural campo/ } \\
\text { cidade. } \\
8^{0} \text { ano: História das relaçóes da } \\
\text { humanidade com o trabalho. O trabalho } \\
\text { e a vida em sociedade. O trabalho e } \\
\text { as contradiçóes da modernidade. Os } \\
\text { trabalhadores e as conquistas de direito. } \\
90 \text { ano: A constituição das instituiçóes } \\
\text { sociais. A formação do Estado. Sujeitos, } \\
\text { guerras e revoluçóes. }\end{array}$ & $\begin{array}{l}\text { Tema } 1 \text { - Trabalho Escravo, Servil, } \\
\text { Assalariado e o Trabalho Livre. } \\
\text { Tema } 2 \text { - Urbanizaçáo e industrializaçáo. } \\
\text { Tema } 3 \text { - O Estado e as relaçóes de poder. } \\
\text { Tema } 4 \text { - Os sujeitos, as revoltas e as } \\
\text { guerras. } \\
\text { Tema } 5 \text { - Movimentos sociais, políticos e } \\
\text { culturais e as guerras e revoluçóes. } \\
\text { Tema } 6 \text { - Cultura e religiosidade. }\end{array}$ \\
\hline
\end{tabular}

Efetivamente, encontramos um maior detalhamento sobre as finalidades de cada segmento de ensino, assim como quanto à definição dos conteúdos para a disciplina de História, visto que, na proposta em questão, assume-se a 
organização dos conteúdos por disciplina. Dessa forma, consegue-se identificar aspectos no que concerne à progressão do conhecimento em História. Para os anos finais do ensino fundamental, indica-se o trabalho com a história local e do Brasil, relacionadas ao contexto mundial, a partir de recortes temáticos. O objetivo é que o aluno aprofunde seus conhecimentos sobre a realidade contemporânea e reconheça quais as implicações do passado na constituição da mesma. Para o ensino médio, assume-se a perspectiva de aliar o ensino da História à busca de soluçóes para temas/problemas. Considerando a necessidade de aprofundamento em relação à complexidade conceitual, indica-se a História Temática como proposta curricular para o ensino médio. Na listagem de conteúdos básicos, identifica-se a possibilidade de efetivação da proposta em questáo, pois os conteúdos destinados ao ensino fundamental oferecem potencialidades para o trato da história local e do Brasil, a partir de diferentes temas, ao passo que os indicados para o ensino médio possibilitam várias composiçôes temáticas.

Ao trazer essa análise sobre os documentos que regem o ensino no país e, mais especificamente, o ensino de História no Paraná, deixa-se em aberto a necessidade de ampliar o enfoque a partir do estudo de outras propostas curriculares. Alerta-se também que, em nosso país, a autonomia da escola e do professor na composição da proposta curricular é garantida por Lei, conforme destacado nas Diretrizes Curriculares Nacionais:

[...] não há, na LDB, relação direta entre obrigatoriedade e formato ou modalidade do componente curricular (seja chamado de estudo, conhecimento, ensino, matéria, conteúdo, componente ou disciplina). [...] não há sua obrigatoriedade para nenhum componente curricular, seja da base nacional comum, seja da parte diversificada. As escolas têm garantida a autonomia quanto à sua concepção pedagógica e para a formulação de sua correspondente proposta curricular, sempre que o interesse do processo de aprendizagem assim o recomendar, dando-lhe o formato que julgarem compatível com a sua proposta de trabalho. (BRASIL, 2013a, p. 186).

Se tal autonomia favorece a construção de um processo mais significativo de ensino e aprendizagem da História, ou se a mesma está impedindo a construção de uma base mínima para o que deve ser ensinado nas escolas, é 
outra necessária e difícil discussão. No que tange aos livros didáticos é fato que os mesmos são construídos a partir da concepção do que seja o cenário nacional quanto ao ensino de História, o que amplia a possibilidade de inserção em diferentes localidades.

\section{O livro didático de História: qual currículo? Qual aprendizagem? Qual progressão?}

Em sentido stricto, pode-se definir o livro didático como um dispositivo que contém uma práxis social enunciativa e uma situação comunicativa destinada ao uso escolar, na qual se articulam objetivos educacionais. Isso significa definir para que se ensina, de acordo com as políticas educacionais públicas e as demandas sociais de seu tempo; delimitar o que se ensina, de acordo com cada ciência de referência, com os conteúdos disciplinares; estabelecer como se ensina e como se aprende, de modo a operar pressupostos pedagógicos e metodológicos pertinentes.

Essas articulações são sempre complexas, pois transversalizadas e mediadas pela cultura escolar, isto é, pelo modo como os sujeitos vivem a experiência educativa em cada tempo, em cada lugar. Os livros produzidos especialmente para o uso escolar têm uma finalidade didática, isso significa dizer que são escritos para auxiliar nos processos de ensino e aprendizagem, pressupondo o aluno - o sujeito da aprendizagem - como um usuário ideal. Nessa direção, a construção de um livro didático, ao dialogar estreitamente com as questóes do currículo e do desenvolvimento cognitivo, exige que se evoquem noçóes de ordenamento, sequência, continuidade, gradualidade, progressão. A pergunta que orienta essa parte do texto diz respeito aos fundamentos (ou aspectos, critérios) que regem a noção de progressão do conhecimento operada na elaboração das duas coleçóes que constituem o corpus documental da pesquisa.

Consoante o enfoque temático, que trata da transição educativa do ensino fundamental para o médio, foram selecionadas duas coleções didáticas bastante atuais, uma referente aos anos finais do ensino fundamental ( $6^{\circ}$ ao $9^{\circ}$ anos) e outra destinada ao ensino médio ( $1^{\circ}$ ao $3^{\circ}$ anos), ambas bem avaliadas pelo Programa Nacional do Livro Didático (PNLD) nos anos de 2012 e 2014. Trata-se de coleçóes publicadas pela Moderna, uma editora cujas vendas para o Fundo Nacional de Desenvolvimento da Educação (FNDE) atingiram, entre 2005 e 2013, o expressivo número de 218.488.239 exemplares, fazendo desta 
empresa a maior fornecedora de livros didáticos no âmbito do PNLD (ensino fundamental e ensino médio) neste período ${ }^{1}$.

O corpus documental é constituído das seguintes coleçóes:

- Ensino fundamental: BRAICK, Patrícia Ramos. Estudar História: das origens do homem à era digital (4 v., 1. ed.). São Paulo: Moderna, 2011².

- Ensino médio: BRAICK, Patrícia Ramos; MOTA, Myriam Becho ${ }^{3}$ (3 v., 3 ed.). História: das cavernas ao terceiro milênio. São Paulo: Moderna, 2013.

No esforço de compreender quais operaçóes de ordenamento as duas coleções mobilizam (e como o fazem), com vistas a garantir situações de sequência, gradualidade e progressão dos conteúdos e dos procedimentos didáticos, estabelecemos um olhar comparativo entre ambas. Primeiramente, realizamos uma leitura flutuante nas obras (BARDIN, 1977), deixando-nos tomar por impressóes e orientaçóes iniciais acerca de seu conjunto. Na sequência, diante das muitas possibilidades de análise que se apresentam num universo de mais de mil e oitocentas páginas, tomamos a decisão de trabalhar a partir de quatro unidades de registro que dessem condiçóes de observar a presença (ou náo) de estratégias de complexificaçáo entre as duas coleçóes. Sáo unidades de registro: 1) Projeto gráfico-editorial; 2) Ordenação dos conteúdos; 3) Abordagem de conteúdos no texto principal; 4) Atividades.

Importante esclarecer que não entraremos no mérito de discutir a adequação ou não das propostas analisadas em cada unidade de registro, limitando-nos identificar quais são as estratégias mobilizadas nas duas coleçôes para dar conta da progressáo do conhecimento histórico. Dito em outras palavras, não nos deteremos em analisar se na abordagem dos trechos aqui destacados, as coleçôes incorrem em erros conceituais, informaçóes parciais ou descontextualizadas, simplificaçóes explicativas, anacronismos, desatualizaçóes historiográficas, inconsistências metodológicas ou quaisquer outras situaçóes de inadequação histórica e pedagógica.

\section{Projeto gráfico-editorial}

Iniciemos pelos aspectos mais visíveis, que são as opçóes referentes ao projeto gráfico editorial, isto é, o modo como as coleçóes sáo estruturadas e apresentadas. Há muitas características em comum, como, por exemplo, a mesma distribuição dos capítulos; a presença de seções, boxes, mapas, imagens e glossário na mesma proporção quantitativa, a forma de hierarquização de títulos 
e subtítulos, com o uso de cores, tons e fontes específicas, inúmeros mapas e imagens (fotografias, pinturas) repetidos nas duas coleçóes, dentre outros.

Como aspectos diferenciadores, identificamos a fonte ligeiramente menor na coleção do ensino médio; a extensão do texto principal, mais entrecortada por subtítulos na coleção do ensino fundamental; maior presença de textos autorais na coleção do ensino fundamental e maior presença de excertos de outras obras e autores na coleção do ensino médio.

Quanto ao sumário, apresenta-se ilustrado na coleção do ensino fundamental, com uma imagem representativa do tema do respectivo capítulo, por exemplo, uma fotografia das ruínas da Acrópole de Atenas no capítulo intitulado A civilização grega (BRAICK, 2011, p. 8, v. 6), ao passo que o sumário da coleção de ensino médio não contém ilustraçôes.

A presença de glossário à margem da página é uma estratégia presente tanto na coleção do ensino fundamental quanto na do ensino médio. Num primeiro olhar, parece haver preocupação em oferecer elementos mais concretos para compreensão dos alunos do ensino fundamental e aspectos mais formais no caso dos alunos do ensino médio. Por exemplo, no volume do $6^{\circ}$ ano define-se o arqueólogo como "pesquisador que estuda armas de pedra, pinturas rupestres, fósseis, pedaços de cerâmica e outros vestígios descobertos em escavaçôes arqueológicas, deixados por povos que viveram em um passado bem distante" (BRAICK, 2011, p. 16). No volume do $1^{\circ}$ ano do ensino médio consta a definiçấo de arqueologia em termos mais formais, como "ciência que estuda a vida e a cultura dos povos antigos, principalmente pela análise e interpretaçấo de vestígios materiais encontrados" (BRAICK; MOTA, 2013, p. 12). Num olhar mais atento, essa impressáo de complexificação se desfaz na medida em que, no segundo exemplo, embora o glossário não especifique o que seriam os vestígios materiais, essa informação é disponibilizada no texto ao lado, nos seguintes termos: "a arqueologia busca informaçóes nos vestígios materiais, como armamentos, utensílios domésticos e ferramentas de trabalho" (BRAICK; MOTA, 2013, p. 12).

Um segundo aspecto a destacar na estratégia do glossário é uma recorrência maior a conceitos formais buscados em outros autores/obras, no caso da coleção de ensino médio. Ainda tratando do glossário, na maioria dos casos as definiçóes são muito semelhantes (ou até idênticas) nas duas coleçóes, sem evidência de cuidado com a complexificação. Tomemos a definição de Siäo, para exemplificar: "Nome usado pelos judeus para designar Jerusalém e a Terra Prometida" (BRAICK, 2011, p. 129, v. 6; BRAICK; MOTA, 2013, p. 
70, v. 1). Em nenhuma das coleçóes se detalha a origem da palavra (em árabe, Tzion), que remete a uma colina localizada a sudeste de Jerusalém, onde havia uma fortaleza de mesmo nome, conquistada pelo Rei Davi.

No tratamento iconográfico não se evidenciam, via de regra, estratégias de complexificação, havendo muitas imagens repetidas nos dois segmentos. Por exemplo, no v. 2 do ensino médio, no capítulo intitulado $A$ mineração no Brasil colonial, consta a imagem de barras de ouro, com a seguinte legenda: "Barras de ouro quintadas, século XVIII. Museu Histórico Nacional, Rio de Janeiro. O ouro em forma de pó ou de pepita era transformado em barras nas casas de fundiçáa" (BRAICK; MOTA, 2013, p. 59). A mesma imagem aparece no v. 8 do ensino fundamental, no capítulo igualmente nomeado A mineração no Brasil, com a legenda: "Barras de ouro quintadas. Museu Histórico Nacional, Rio de Janeiro. Nas casas de fundição, recolhia-se o quinto, parte que cabia à Coroa. $\mathrm{O}$ restante era transformado em barras identificadas com o selo real" (BRAICK, 2011, p. 34). Exatamente a mesma situação pode ser exemplificada no v. 3, p. 117 e no v. 9, p. 185, onde se encontram duas imagens idênticas referentes ao governo de Mao Tsé Tung, nas quais crianças uniformizadas leem o Livro Vermelho, sob o retrato deste governante.

$\mathrm{Na}$ maioria das situações as imagens são diferentes nas duas coleções, todavia, invariavelmente cumprem a mesma função ilustrativa e os mesmos propósitos relativos ao conteúdo. Localizamos um caso exemplar no estudo da produção cultural no contexto da Guerra Fria, em que constam fotografias de jovens dançando ao som de rock and roll e de twist, em Londres e em Frankfurt, respectivamente, para ilustrar os novos padróes de comportamento trazidos com o gênero musical emergente na época. Vejamos as imagens:

Figura 1 - Jovens dançando rock and roll

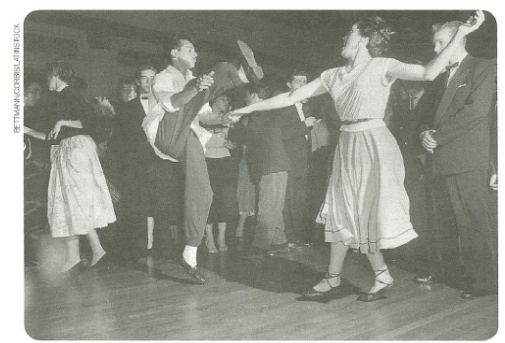

Fonte: BRAICK, 2011, p. 192.
Figura 2 -Jovens dançando twist

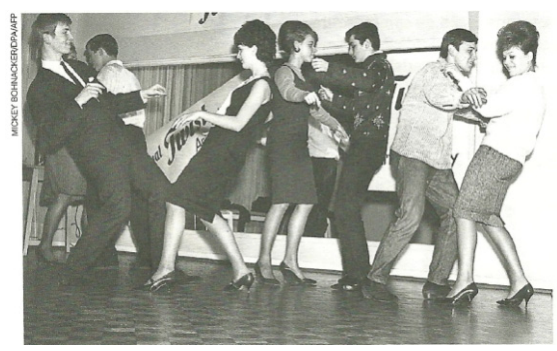

Fonte: BRAICK, MOTA, 2013, p. 124. 
$\mathrm{Na}$ figura 1, referente à obra do ensino fundamental (BRAICK, 2011, p. 192), a legenda da fotografia indica: "Jovens britânicos dançam rock and roll em saláo de baile de Londres, Inglaterra, em 1959”. Na figura 2, pertencente ao livro do ensino médio (BRAICK, MOTA, 2013, p. 124), consta a seguinte legenda: "Jovens alemães ocidentais aprendem os primeiros passos do twist em uma escola de dança em Frankfurt, na entâo Alemanha Ocidental, em 1961". O que importa destacar, nesse caso, é que ambas as imagens têm exatamente a mesma finalidade nas duas coleções, sem qualquer atenção à complexificação da abordagem diante de jovens que têm cerca de três anos de diferença de idade. Tomando-se como regra o fluxo "normal" de escolarização, isto é, sem considerar os casos de defasagem série/idade, podemos dizer que um jovem que frequenta o $9^{\circ}$ ano do ensino fundamental tem aproximadamente 14-15 anos, ao passo que estudantes do $3^{\circ}$ ano do ensino médio estão entre 17 e 18 anos de idade. Essas diferentes experiências parecem ser desconsideradas na proposta do livro didático, neste e em outros muitos casos.

\section{Ordenação dos conteúdos}

A segunda unidade de registro destacada para análise, nos limites deste artigo, trata do modo como as coleçóes selecionam os conteúdos a ensinar, do ponto de vista da estruturação curricular. Isso implica observar quais conhecimentos históricos são selecionados, qual organização temporal é eleita, qual recorte temático é operado, dentre outros aspectos. Para dar conta dessas questôes, reproduzimos o sumário das duas coleçōes no quadro 4.

Quadro 4-Comparativo da ordenaçáo dos conteúdos nas coleçóes

\begin{tabular}{|c|c|}
\hline $\begin{array}{l}\text { Estudar História: das origens do homem à } \\
\text { era digital (BRAICK, 2011) }\end{array}$ & $\begin{array}{l}\text { História: das cavernas ao terceiro milênio } \\
\text { (BRAICK, MOTA, 2013) }\end{array}$ \\
\hline $\begin{array}{l}\text { 6o ANO - } 216 \text { páginas e } 12 \text { capítulos: } \\
\text { O que é história? } \\
\text { A história, o tempo e o espaço. } \\
\text { O ser humano em busca de suas origens. } \\
\text { A origem das cidades. } \\
\text { Os primeiros habitantes da América. } \\
\text { Mesopotâmia e Egito. } \\
\text { A Núbia e o reino de Cuxe. } \\
\text { Hebreus e fenícios. } \\
\text { A civilização grega } \\
\text { Cultura e cotidiano na Grécia antiga. } \\
\text { A civilização romana. } \\
\text { Expansão e crise do Império Romano. }\end{array}$ & $\begin{array}{l}\text { 10 ANO - } 248 \text { páginas e } 14 \text { capítulos: } \\
\text { A construção da história. } \\
\text { Da origem do ser humano à formação dos } \\
\text { primeiros Estados. } \\
\text { A identidade do homem americano. } \\
\text { Antiguidade oriental. } \\
\text { Grécia: berço da civilização ocidental } \\
\text { O esplendor de Roma. }\end{array}$ \\
\hline
\end{tabular}




\begin{tabular}{|c|c|}
\hline $\begin{array}{l}\text { 70 ANO - } 288 \text { páginas e } 13 \text { capítulos: } \\
\text { A alta Idade Média e a formação do feudalismo. } \\
\text { Nascimento e expansão do Islã. } \\
\text { A África antes dos europeus. } \\
\text { Impérios do Oriente: China e Japão. } \\
\text { A baixa Idade Média e a crise do feudalismo. } \\
\text { O renascimento cultural. } \\
\text { Reformas religiosas na Europa. } \\
\text { A formação dos Estados Nacionais europeus. } \\
\text { As grandes navegaçóes. } \\
\text { A América pré-colombiana. } \\
\text { A colonização espanhola na América. } \\
\text { A conquista e a colonização da América } \\
\text { Portuguesa. } \\
\text { O Nordeste açucareiro. } \\
\text { Ingleses, franceses e holandeses na América. }\end{array}$ & $\begin{array}{l}\text { Alta Idade Média } \\
\text { A civilização bizantina e o Islã. } \\
\text { Baixa Idade Média } \\
\text { A consolidaçáo das monarquias na Europa } \\
\text { moderna. } \\
\text { O Renascimento e as formas religiosas. } \\
\text { A expansão ultramarina europeia e o } \\
\text { mercantilismo. } \\
\text { As culturas indígenas americanas. } \\
\text { A África dos grandes reinos e impérios. } \\
\text { 2o ANO - } 248 \text { páginas e } 16 \text { capítulos: } \\
\text { A Colonização da América espanhola. } \\
\text { A colonização da América inglesa e francesa. } \\
\text { Organizaçáo político-administrativa na } \\
\text { América-portuguesa. } \\
\text { A economia na América portuguesa e o Brasil } \\
\text { holandês. }\end{array}$ \\
\hline $\begin{array}{l}8^{\circ} \text { ANO - } 288 \text { páginas e } 15 \text { capítulos: } \\
\text { A expansão da América portuguesa. } \\
\text { A mineraçáo no Brasil. } \\
\text { As revoluçóes inglesas do século XVII. } \\
\text { O Iluminismo. } \\
\text { A revolução industrial. } \\
\text { A independência dos Estados Unidos. } \\
\text { A Revolução Francesa. } \\
\text { O império napoleônico e o Congresso de } \\
\text { Viena. } \\
\text { A independência do Haiti e das colônias } \\
\text { espanholas. } \\
\text { O processo de independência do Brasil. } \\
\text { As revoluçôes liberais e os movimentos } \\
\text { nacionalistas. } \\
\text { As lutas operárias e as novas teorias políticas. } \\
\text { Brasil: o Primeiro Reinado e as Regências. } \\
\text { O Segundo Reinado. } \\
\text { Os Estados Unidos no século XIX. }\end{array}$ & $\begin{array}{l}\text { A mineração do Brasil colonial. } \\
\text { Religião e sociedade na América portuguesa. } \\
\text { O iluminismo. } \\
\text { Das Revoluções Inglesas à Revolução } \\
\text { Industrial. } \\
\text { A Revolução Francesa e o Império } \\
\text { Napoleônico. } \\
\text { As lutas de independência na América. } \\
\text { O processo de independência da América } \\
\text { portuguesa. } \\
\text { O movimento operário e o advento do } \\
\text { socialismo. } \\
\text { As revoluçóes liberais e o nacionalismo. } \\
\text { O governo de D. Pedro I e o período regencial. } \\
\text { O governo de D. Pedro II. } \\
\text { Os Estados Unidos e a América hispânica no } \\
\text { pós-independência. }\end{array}$ \\
\hline
\end{tabular}




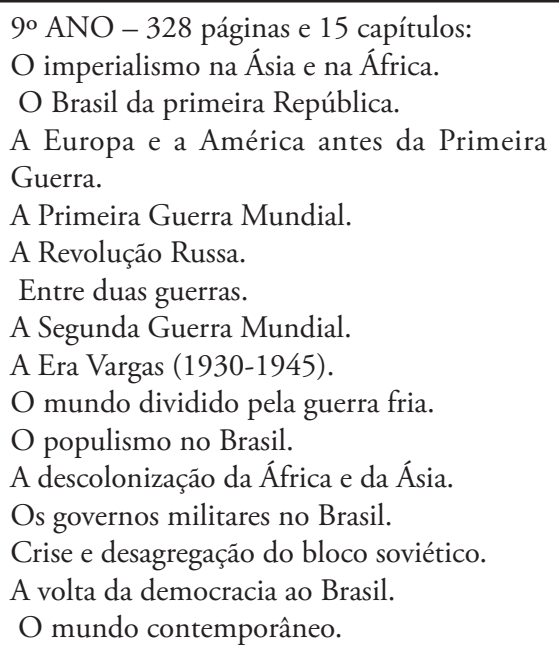

$3^{\circ} \mathrm{ANO}-272$ páginas e 13 capítulos:

O imperialismo na África e na Ásia.

O Brasil na Primeira República.

A Primeira Guerra Mundial.

A crise dos anos 1920 e a ascensão nazifascista.

A Segunda Guerra Mundial.

A Era Vargas.

A Guerra Fria.

Os processos de emancipaçáo na África e na Ásia.

Governos populistas na América Latina. Ditaduras militares na América Latina.

O fim do socialismo real.

Brasil: da redemocratização aos dias atuais. O mundo globalizado e seus principais desafios.

Fonte: BRAICK, 2011, 4 volumes; BRAICK; MOTA, 2013, 3 volumes.

Começando pelas manifestações mais aparentes, podemos dizer que as obras se equivalem em número de páginas, uma vez que a coleção do ensino fundamental contém 1.120 páginas distribuídas em quatro anos e a coleção do ensino médio contempla 768 páginas distribuídas em três anos letivos. Assim, a quantidade de conteúdos/páginas não é um fator relevante de diferenciação curricular entre os dois segmentos.

No que diz respeito à estruturação curricular dos conhecimentos históricos, ambas as coleçóes se compóem na perspectiva da chamada história integrada, obedecendo a uma cronologia linear crescente dos conteúdos, desde as sociedades ágrafas até o mundo contemporâneo, incorporando alternadamente abordagens da história geral, da América e do Brasil. O formato é, basicamente, o quadripartismo (história antiga, medieval, moderna e contemporânea) no tratamento da história geral e o tripartismo (colônia, império e república) na abordagem da história do Brasil ${ }^{4}$.

Os sumários das duas coleçóes, reproduzidos lado a lado no Quadro 4, mostram que os conteúdos selecionados são rigorosamente os mesmos, sendo apresentados na mesma sequência, com adaptação apenas no que tange à distribuição nos respectivos anos. Notemos que os conteúdos dos três primeiros volumes do ensino fundamental correspondem aos dois primeiros volumes do ensino médio, restando ao último volume de cada segmento, respectivamente 
o $9^{\circ}$ ano do ensino fundamental e o $3^{\circ}$ ano do ensino médio, praticamente o mesmo recorte temporal, no caso, o estudo do mundo contemporâneo.

Fica evidente, assim, que tanto no ensino fundamental quanto no ensino médio, não se opera qualquer lógica específica de recorte dos conteúdos, ou seja, tem-se a ambiçáo de estudar "toda a história" nos dois segmentos, repetindo a mesma cronologia, os mesmos conteúdos, com pouca (pode-se dizer quase nenhuma) gradualidade curricular. Essa evidência não fica restrita às coleçóes que constituem o corpus documental desta pesquisa, podendo ser generalizada para cerca de $90 \%$ das obras didáticas disponíveis hoje no mercado editorial. Para ilustrar a afirmação, mostramos que no conjunto das vinte coleçóes de ensino fundamental que integram o Guia de Livros Didáticos: PNLD 2014 - História (BRASIL, 2013b), apenas duas se distinguem dessa estrutura curricular dita "Integrada", uma vez que se organizam por temas ou eixos temáticos.

Diante da constatação de que essa estruturação curricular do conhecimento histórico é hegemônica na produção didática e considerando que o livro didático de História ocupa um lugar bastante significativo no espaço escolar figurando, não raras vezes, como plano de estudos da disciplina, é preciso indagar sobre as razóes de tal hegemonia. Em síntese, por que persistimos na desmedida ambição de ensinar toda a história no ensino fundamental e repetir essa síntese histórica no ensino médio? Por que não ousamos experimentar outros ordenamentos curriculares, outros recortes historiográficos, outras opções temáticas? Cerri (2009) indica a "força de inércia de repouso das permanências" para ilustrar a longevidade das abordagens quadripartites e tripartites no currículo da história escolar. Seguindo na análise, levanta a hipótese de que é no âmbito da formação dos professores de História que podemos compreender essa situação, ou seja, na estruturação da matriz curricular das licenciaturas, no modo de estabelecer o diálogo com a ciência de referência, com a pesquisa histórica. Na medida em que os professores têm sido formados, ao longo de décadas, nessa lógica histórica cronológica, linear, total, torna-se difícil impulsionar outras possibilidades no âmbito da educação básica. De acordo com Cerri (2009, p. 150), "enquanto a academia não for capaz de romper essas estruturas de conteúdo que alicerçaram o surgimento do campo, mas que estão superadas pelo seu próprio desenvolvimento, fica difícil cobrar um avanço mais extenso, profundo e sistemático da história na escola”.

\section{Abordagem de conteúdos no texto principal}

Seguindo nessa ideia de que a abordagem do conhecimento histórico no ensino fundamental e no ensino médio apresenta alto índice de repetiçáo dos 
conteúdos, com pouca progressão e complexificação das informaçôes, conceitos e noçôes, traz-se uma situação exemplar, dentre muitas que poderiam figurar aqui. $\mathrm{O}$ volume do $6^{\circ}$ ano do ensino fundamental apresenta dois capítulos destinados ao estudo da Grécia antiga, intitulados $A$ civilização grega e Cultura e cotidiano na Grécia antiga. O mesmo conteúdo é abordado no volume do $1^{\circ}$ ano do ensino médio, num único capítulo cujo título é Grécia: berço da civilizaçâo ocidental. Vejamos, no quadro 5, o cotejo das abordagens sobre as especificidades da educação destinada aos jovens na cidade-Estado de Esparta.

Quadro 5 - Comparativo da abordagem textual das duas coleçóes

\begin{tabular}{|c|c|}
\hline BRAICK, 2011, p. 148, v. 6 & BRAICK; MOTA, 2013, p. 81, v. 1 \\
\hline $\begin{array}{l}\text { Educaçáo voltada para guerra } \\
\text { A educaçáo espartana se orientava a formar } \\
\text { futuros guerreiros e cidadáos leais à pólis. Por } \\
\text { essa razão, só se aprendia o mínimo necessário } \\
\text { das letras, do canto e da dança. } \\
\text { Aos sete anos, os rapazes das famílias ricas } \\
\text { saíam de casa e iam viver em quartéis, onde } \\
\text { permaneciam até por volta dos seus trinta } \\
\text { anos. Lá, o treinamento consistia em exercícios } \\
\text { de preparaçáo física, ginástica e atletismo. A } \\
\text { disciplina era táo rígida que incluía castigos } \\
\text { físicos por parte dos professores. } \\
\text { Ao sair dos quartéis, o cidadão devia casar } \\
\text { e ter filhos, mas não podia ter uma rotina } \\
\text { familiar. Por exemplo, os homens deviam } \\
\text { comer juntos, e não no convívio com a família. } \\
\text { Um cidadão espartano podia ser chamado para } \\
\text { ir à guerra até os sessenta anos. } \\
\text { As mulheres de Esparta praticavam exercícios } \\
\text { e participavam dos jogos. Desde a infância, } \\
\text { elas passavam por treinamento físico e } \\
\text { psicológico e se preparavam para a vida de } \\
\text { mães e esposas de guerreiros. } \\
\text { As espartanas também frequentavam } \\
\text { reunióes públicas, praticavam esportes } \\
\text { e ajudavam os maridos a administrar a } \\
\text { economia familiar; portanto, tinham mais } \\
\text { liberdade que as mulheres de qualquer outra } \\
\text { cidade da Grécia. }\end{array}$ & $\begin{array}{l}\text { Esparta: educação para a guerra } \\
\text { A educação espartana visava à formação de } \\
\text { bons soldados e cidadãos leais, privilegiando } \\
\text { a preparaçáo física e militar. A partir dos } \\
\text { sete anos, os meninos eram entregues ao } \\
\text { Estado, que procurava fazer deles soldados } \\
\text { obedientes e capazes de resistir às fadigas. } \\
\text { Nos acampamentos militares, para onde eram } \\
\text { levados, os jovens eram submetidos à fome, ao } \\
\text { frio e aos castigos físicos, visando prepará-los, } \\
\text { física e emocionalmente, para os sacrifícios } \\
\text { da guerra. } \\
\text { As mulheres também recebiam, desde a } \\
\text { infância, um rigoroso treinamento físico e } \\
\text { psicológico, esperando, assim, que gerassem } \\
\text { crianças robustas e saudáveis. Durante sua } \\
\text { educação, as mulheres aprendiam a colocar } \\
\text { o amor à pólis acima do amor pela família } \\
\text { (filhos e marido). As espartanas gozavam de } \\
\text { algumas liberdades inexistentes em outras } \\
\text { cidades-Estado da Grécia. Por exemplo, } \\
\text { elas praticavam ginástica, participavam de } \\
\text { jogos e circulavam livremente pela cidade. } \\
\text { Também podiam comparecer às reuniôes } \\
\text { públicas e compartilhar com o marido a } \\
\text { administraçáo do lar. Em casa, tudo indica } \\
\text { que elas tivessem uma relaçáo de diálogo com } \\
\text { o marido, encorajando-o, inclusive em sua } \\
\text { vocação guerreira. Mas, ainda que tivessem } \\
\text { mais autonomia que as mulheres gregas de } \\
\text { outras poleis, as espartanas não possuíam } \\
\text { direitos políticos. }\end{array}$ \\
\hline
\end{tabular}


Considerando a possibilidade de estes textos serem estudados por jovens de cerca de 11-12 anos no $6^{\circ}$ ano do ensino fundamental e jovens de 14-15 anos no $1^{\circ}$ ano do ensino médio, não nos parece haver qualquer diferenciação de complexidade no que diz respeito à estrutura textual, ao vocabulário adotado, aos conceitos apresentados. A rigor, podemos até indicar alguns termos e conceitos de maior dificuldade no texto do $6^{\circ}$ ano. Por exemplo, no primeiro texto $\left(6^{\circ}\right.$ ano) usa-se a expressão "administrar a economia familiar" para comentar os papeis conjugais, ao passo que no segundo texto $\left(1^{\circ}\right.$ ano $)$ adota-se uma expressáo mais simples e direta, como "administração do lar".

\section{Atividades}

Chegando aos limites do espaço que o artigo comporta, debruçamo-nos sobre algumas atividades que as coleçóes apresentam, tanto para a fixação dos conteúdos quanto para o desenvolvimento de habilidades de compreensão, análise, interpretação, síntese etc. Seguindo o propósito de identificar estratégias de progressão e complexificação da aprendizagem histórica, recorta-se dois grupos de atividades que comportam estratégias semelhantes, pertinentes ao mesmo tema, em cada coleção: o primeiro grupo referente aos capítulos da Segunda Guerra Mundial (assim nomeado nos dois segmentos) e o segundo grupo relativo aos capítulos Os governos militares no Brasil (ensino fundamental) e Ditaduras militares na América Latina (ensino médio).

As figuras 3 e 4, a seguir, ilustram o primeiro grupo de atividades: 

os níveis fundamental e médio

Figura 3 - Atividade v. 9

4. Atividade em dupla. Leiam o texto a seguir e respondam às questões.

"A exigência que Auschwitz não se repita é a primeira de todas as metas para a educação [...] Ela foi a barbárie contra a qual se dirige a educação. [...] Milhões de pessaas inocentes só o simples fato de citar númeras já é humanamente indigno, quanto mais discutir quantidades - foram assassinadas de uma maneira planejada. Ista não pode ser minimizado por nenhuma pessoa viva como senda um fenômeno superficial, como sendo uma aberração no curso da história, que não importa, em face da tendência dominante do progresso, do esclarecimento, do humanismo supostamente crescente."

ADORNO, Theodor. Educação após Auschwitz. In: Educação e emancipação. Rio de Janeiro: Paz e Terra, 1995. p. 119-154.

a) Qual fato marcante na Segunda Guerra Mundial é o assunto desse texto?

b) Qual é a ideia principal defendida pelo autor?

c) Por que o autor deu a esse texto o título "Educação após Auschwitz"?

d) Na opinião de vocês, a escola é um meio de combater a barbárie e a violência? Justifiquem sua posição.

Fonte: BRAICK, 2011, p. 150.
Figura 4 - Atividade v. 3

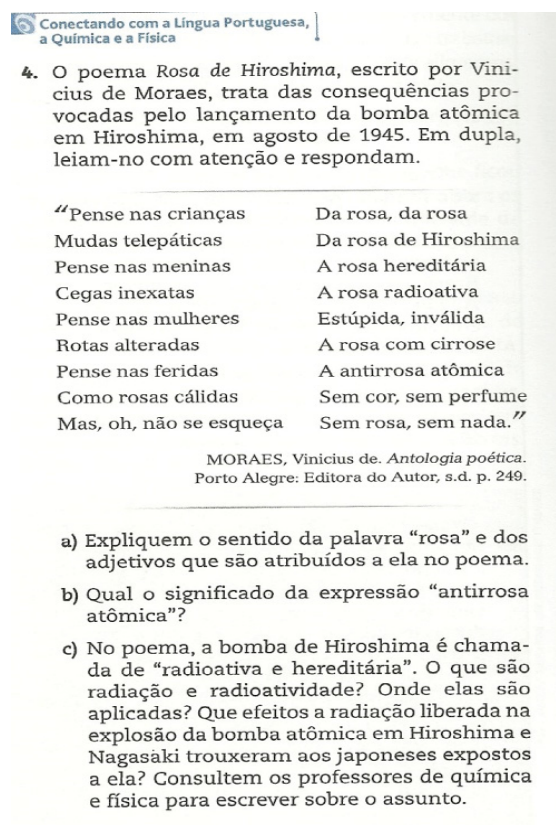

Fonte: BRAICK; MOTA, 2013, p. 88.

$\mathrm{Na}$ atividade do ensino fundamental (figura 3), os alunos são instados a ler, em duplas, um excerto da obra de Theodor Adorno para, posteriormente, responder três questôes de interpretação do texto e uma questâo de posicionamento argumentativo. $\mathrm{Na}$ atividade do ensino médio (figura 4), a tarefa de leitura e interpretação do poema Rosa de Hiroshima, de Vinícius de Moraes também é solicitada em duplas. Note-se que o primeiro consiste num texto filosófico, ao passo que o segundo trata-se de um poema. Considerando que o tema da atividade do ensino médio é amplamente divulgado na mídia, com muitas imagens da explosão da bomba atômica, pode-se supor que esta seja, em tese, a atividade menos exigente, do ponto de vista cognitivo, ou seja, aquela que requer menor capacidade interpretativa.

Situação semelhante é identificada no segundo grupo de atividades, de acordo com o exemplo (figuras 5 e 6 ) a seguir: 


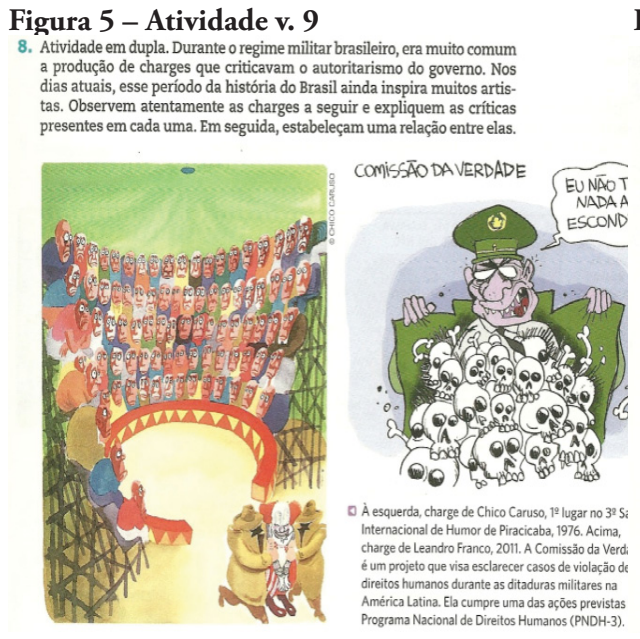

Fonte: BRAICK, 2011, p. 251.

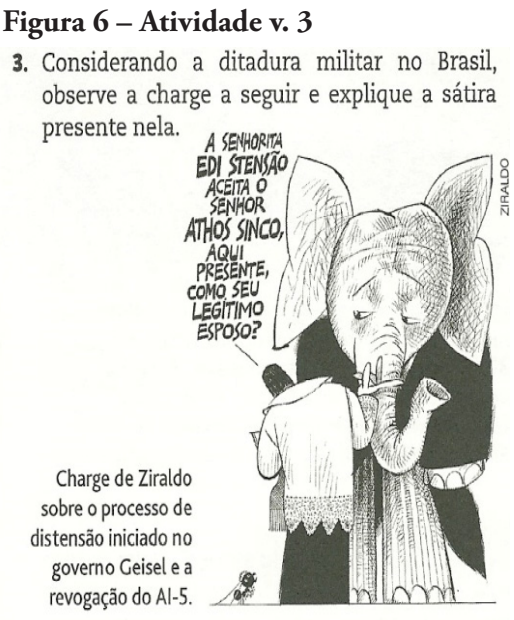

Fonte: BRAICK; MOTA, 2013, p. 198.

A atividade solicitada aos alunos do $9^{\circ}$ ano do ensino fundamental (figura 5) apresenta um grau de complexidade maior do que se requer na atividade do ensino médio (figura 6). Note-se que no comando da atividade do ensino médio se pede que o aluno explique o conteúdo da charge de Ziraldo (uma formiga representando a distensão, casando-se com um elefante representando o Ato Institucional no 5 - AI-5), contando com a legenda que, apesar de não apresentar a data de produçáo, indica os elementos do contexto histórico, o processo de "distensão lenta, gradual e segura", responsável pela progressiva revogação do AI-5.

A habilidade requerida é apenas a de explicar este contexto específico, ao passo que a atividade apresentada no livro do ensino fundamental solicita que se analisem duas charges, que se expliquem cada uma delas e, por fim, se estabeleçam relaçóes entre ambas. Além de ser esta uma operação mais ampla, que mobiliza funçóes cognitivas mais complexas (análise, interpretação, explicação, comparação e síntese), aos alunos são fornecidos menos elementos de apoio. A legenda da charge da esquerda da figura 5, por exemplo, limitase a informar que se trata de uma charge de Chico Caruso, que lhe rendeu

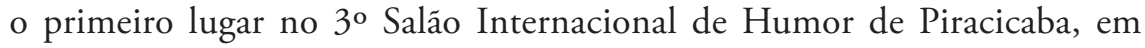
1976. Esta primeira imagem tem visibilidade restrita e, aparentemente, a figura central se trata de um palhaço sendo retirado do picadeiro de um circo 
por dois agentes, sob o olhar (Surpreso? Indiferente? Resignado? Triste? É difícil distinguir) da plateia. O que se percebe, assim, nas duas propostas de atividades, é que não só estão ausentes as estratégias de complexificação crescente entre os dois segmentos, como se exige maior nível de complexidade dos alunos do ensino fundamental.

\section{Considerações Finais}

O estudo sobre a progressão do conhecimento histórico necessita de fontes que forneçam variáveis capazes de marcar permanências e transformaçóes quanto ao processo de ensino e aprendizagem. Trata-se de um tipo de pesquisa na qual se pressupóe a passagem do tempo como condição elementar para a tessitura de conclusôes. Dentre as possibilidades investigativas que se apresentavam, optou-se pelo estudo de propostas curriculares e de livros didáticos nos quais "a passagem do tempo" está representada no conteúdo da História para estudantes ao longo de um determinado período da trajetória escolar.

Segundo Sacristán (1996, p. 24), "gradualidade no processo educativo significa possibilidade de ordenar a aprendizagem, de enlaçar seus componentes e seus momentos para que o ensino fundamente uma concatenaçáo ordenada de componentes aprendidos". O mesmo autor aponta outro conceito, o de continuidade vertical, para fortalecer o argumento da necessidade de uma transição curricular progressiva. Para Sacristán (1996, p. 35), a "continuidade vertical se obtém com a combinação de dois princípios tidos como desejáveis: por um lado, a conveniência de alguma sequência entre os conteúdos que se ensinam e, por outro, a preocupação pela progressáo graduada da experiência e exigências da aprendizagem".

Como possibilidades para efetivar essa continuidade vertical, Sacristán (1996) apresenta quatro principais manifestaçóes, afirmando que outras tantas são admissíveis: 1) a interdependência ou conexão de temas dentro de uma mesma disciplina, ao longo do percurso escolar; 2) o aprofundamento gradual dos mesmos temas de acordo com as possibilidades crescentes dos estudantes, numa espécie de sequência em espiral; 3) a continuidade no tratamento dos temas dentro de uma área do conhecimento, num esforço de trabalho interdisciplinar; 4) a continuidade através do tempo no tratamento de determinados objetivos gerais da educação, que dizem respeito a valores contemporâneos ou habilidades fundamentais, como o desenvolvimento da 
atitude cidadã, a formação do espírito crítico, a capacidade de expressão, o respeito às diferenças, o preparo para o convívio social democrático, dentre outros.

Em síntese, as transiçóes educativas, especialmente as passagens de um nível para outro, devem ser fundamentadas em princípios de graduação, coerência, continuidade, aprofundamento, tendo em vista a progressáo cognitiva. Considerando que do ponto de vista da aprendizagem e do desenvolvimento, qualquer corte é sempre arbitrário, é preciso reconhecer as especificidades individuais, as particularidades da turma, as características da escola, dentre outros.

Ao iniciarmos este estudo indicamos quatro questôes. A primeira desafiava-nos a compreender sobre as habilidades de pensamento histórico que se espera do jovem do ensino médio. Se considerarmos o prescrito nos documentos e nos livros didáticos analisados, não se registra uma efetiva preocupação ao tratar de tal temática. Encontramos uma ou outra abordagem sobre o assunto, geralmente com ênfase para descrever o perfil do adolescente, sem adentrar nas especificidades quanto ao pensamento histórico. Nos livros didáticos identificamos que, por vezes, o que se exige cognitivamente do aluno do ensino médio é inferior às exigências apresentadas para o ensino fundamental.

Em decorrência, torna-se difícil elencar o que se almeja como avanços qualitativos para a última etapa da educação básica. Mas é possível identificar alguns caminhos que podem auxiliar na composiçáo de respostas sobre o assunto. Nas Diretrizes Curriculares do Ensino de História do estado do Paraná a proposta é atingir um maior grau de complexidade na explicação e interpretação históricas e vincular o aprendizado da História à busca de solução para os temas/problemas. Nos livros didáticos é indicar o que se entende por esse avanço qualitativo, visto que a abordagem histórica é muito homogênea.

É recorrente nos documentos analisados a indicação da necessidade de operar recortes de conteúdos, seja pela via da concepção historiográfica, como a proposta de História Temática, seja pela via da concepção metodológica, articulando os conteúdos por meio de eixos temáticos. O que se apresenta no livro didático é a ausência de um recorte de conteúdo, uma vez que a comparação entre os sumários indica a repetição de abordagens sem a devida complexificação quanto ao trato dos assuntos ou quanto às propostas decorrentes dos assuntos 
tratados. Ao se compreender que a ausência de recorte implica na ambição de colocar no livro "toda a história", perde-se o referencial para o trato com a progressão do conhecimento, pois a única progressão que pode ser constatada se relaciona com a quantidade de informaçôes para o aluno armazenar, sobre os mais variados assuntos. A literatura sobre tal questão é exaustiva no sentido de apontar que tal aprendizagem difere-se sobremaneira do que se entende quanto ao desenvolvimento do pensamento histórico. Dessa breve incursão ao tema, resta-nos a convicção de que as questôes referentes à progressão e à complexificaçáo do conhecimento histórico ainda estáo por ser densamente pesquisadas e discutidas entre nós.

\section{Notas}

${ }^{1}$ Segundo dados do FNDE, seguem-se à Editora Moderna, em segundo lugar a Editora FTD, com 192.193.064 exemplares fornecidos entre 2005 e 2013; a Editora Ática, com 185.464.748 exemplares; e a Editora Saraiva, com 154.506.614 exemplares. Essas quatro editoras respondem por mais 70\% do fornecimento de coleçóes didáticas ao PNLD no período em questão. Quantidade de Exemplares de Livros Didáticos Adquiridos por Editora - Ensino Fundamental e Médio. Informaçóes disponíveis em: <http://www.fnde.gov.br/programas/livro-didatico/livro-didaticodados-estatisticos>. Acesso em 27 fev. 2014.

${ }^{2}$ Esta coleção consta como primeira edição em 2011 e integra o Guia do PNLD 2014 - Anos Finais do Ensino Fundamental, com autoria de Patrícia Ramos Braick. Todavia, consta no Guia desde o PNLD 2008 Anos Finais do Ensino Fundamental, sob o título História: das cavernas ao terceiro milênio, e autoria de Patrícia Ramos Braick e Myriam Becho Mota.

${ }^{3} \mathrm{Na}$ coleção destinada ao ensino médio, constam as seguintes informaçôes sobre as autoras: Patrícia Ramos Braick é "mestre em História (área de concentração: História das Sociedades Ibéricas e Americanas) pela Pontifícia Universidade Católica do Rio Grande do Sul. Professora do Ensino Médio em Belo Horizonte". Myriam Becho Mota é apresentada como "licenciada em História pela Faculdade de Ciências Humanas de Itabira, MG. Mestre em Relaçóes Internacionais pela The Ohio University, EUA. Professora do Ensino Médio e Superior em Itabira, MG” (BRAICK; MOTA, 2013). 
${ }^{4}$ Uma consistente análise e crítica dessa organização curricular do conhecimento histórico é encontrada em Chesneaux (1995).

\section{REFERÊNCIAS}

BARDIN, Laurence. Análise de conteúdo. Lisboa: Ediçóes 70, 1977.

BRAICK, Patrícia Ramos. Estudar História: das origens do homem à era digital. São Paulo: Moderna, 2011. 9 v.

BRAICK, Patrícia Ramos; MOTA, Myriam Becho. História: das cavernas ao terceiro milênio. 3. ed. São Paulo: Moderna, 2013. 3 v.

BRASIL. Lei ${ }^{\circ} 9.394,20$ de desembro de 1996. Estabelece as diretrizes e bases da educação nacional. Diário Oficial da União, Brasília, DF, 23 dez. 1996.

BRASIL. Lei $\mathrm{n}^{\circ} 11.645$, de 10 de março 2008. Altera a Lei no 9.394, de 20 de dezembro de 1996, modificada pela Lei no 10.639, de 9 de janeiro de 2003, que estabelece as diretrizes e bases da educação nacional, para incluir no currículo oficial da rede de ensino a obrigatoriedade da temática "História e Cultura Afro-Brasileira e Indígena”. Diário Oficial da União, 11 mar. 2008.

BRASIL. Diretrizes Curriculares Nacionais Gerais da Educação Básica. Brasília, DF: MEC; SEB, $2013 a$.

BRASIL. Guia de livros didáticos: PNLD 2014 - História. Ensino fundamental: anos finais. Brasília, DF: MEC; SEB, 2013 b.

CERRI, Luis Fernando. Recortes e organizaçôes de conteúdos históricos para a educação básica. Antiteses, Londrina, PR,v. 2, n. 3, p. 131-152, jan./ jun. 2009.

CHESNEAUX, Jean. Devemos fazer tabula rasa do passado? Sobre a história e os historiadores. São Paulo: Ática, 1995.

LIBÂNEO, José Carlos. Conteúdos, formação de competências cognitivas e ensino com pesquisa. In: PIMENTA, Selma Garrido; ALMEIDA, Maria Isabel de (Org.). Pedagogia Universitária: caminhos para a formação de professores. São Paulo: Cortez, 2011. p. 188-212. 
MOEHLECKE, Sabrina. O ensino médio e as novas diretrizes curriculares nacionais: entre recorrências e novas inquietaçôes. Revista Brasileira de Educação. Rio de Janeiro, v. 17, n. 49, p. 39-58, jan./abr. 2012.

OTANO, Luís. Los retos de esta transición. Cuadernos de Pedagogía, n. 282, Julio-Agosto/1999. Barcelona, Editorial Praxis, S.A., p. 52-57.

PARANÁ. Diretrizes Curriculares da Educação Básica. História. Secretaria de Estado da Educação do Paraná. Departamento de Educação Básica. Curitiba, 2008.

SACRISTÁN, José Gimeno. La transición a la educación secundaria: discontinuidades en las culturas escolares. Madrid: Morata, 1996.

SACRISTÁN, José Gimeno (Org.). Saberes e incertezas sobre o currículo. Porto Alegre: Penso, 2013.

SÁNCHEZ, Jesús Jiménez. O currículo da educação secundária. In: SACRISTÁN, José Gimeno (Org.). Saberes e incertezas sobre o currículo. Porto Alegre: Penso, 2013, p. 370-384.

THURLER, M. G.; MAULINI, Olivier (Org.). A organização do trabalho escolar: uma oportunidade para repensar a escola. Porto Alegre: Penso, 2012. 


\section{La progresión del conocimiento histórico en la educación básica: dilemas de la transición entre el nivel fundamental y medio}

\section{Resumen}

El estudio parte del principio de que la organización del trabajo escolar, en este caso, lo que se refiere a la enseñanza y al aprendizaje del conocimiento histórico, implica realizar articulaciones calificadas entre la epistemología de la ciencia de referencia y el desarrollo de las capacidades y habilidades del pensamiento de los alumnos. Si consideramos que en la tarea de enseñar hay que reconocer tanto la adquisición de contenidos cuanto a las capacidades de pensar/aprender, el esfuerzo para garantizar la progresión racional de la enseñanza con vista a la complejidad del aprendizaje gana especial destaque. En la presente investigación fueron priorizadas algunas especificidades en relación a los procesos de enseñanza y aprendizaje de la Historia en la enseñanza fundamental y media, tanto del punto de vista de la organización curricular de los contenidos, cuanto de las capacidades cognitivas del sujeto que aprende, considerando la progresión de la complejidad de los contenidos, conceptos, nociones y metodologías. Después de realizar una revisión de la literatura pertinente y de algunos documentos curriculares, se prioriza el análisis en dos colecciones didácticas
The progression of the historical knowledge in basic education: dilemmas in the transition between basic and high school

\begin{abstract}
This study starts from the premise that the scholar work organization, in what concerns the historical knowledge teaching/learning, demands qualified links between the reference science epistemology and the student's thinking abilities and capacities development. If we consider that in the teaching task we must recognize both the acquisition of contents and the capacities of thinking/ learning, the effort to guarantee the rational progression of the education become very important. In this study, we list some specificities of the history teaching/learning process in the basic and high school, considering the curricular content organization and the cognitive abilities of the student, having in mind the complexity of contents, concepts, notions and methodologies. After revisit the pertinent literature and some curricular documents, we base the analysis in two History didactical collections - one from each segment - aiming to identify wich decisions are taken in the organization of the historical and pedagogical proposal and analyze how the historical knowledge progression is understood/realized. The preliminary results show that there are few references to the historical
\end{abstract}


de Historia, una de cada sector, con el intuito de identificar que decisiones son tomadas en la organización de la propuesta histórica y pedagógica y analizar cómo es entendida/efectuada la progresión del conocimiento histórico entre ellas. Los resultados preliminares señalan que son escasas las referencias a la progresión del conocimiento histórico en los materiales analizados, lo que se traduce en la dificultad de apuntar lo que se desea como avances cualitativos para la última etapa de la educación básica. De tal forma, el poco progreso constatado en los documentos cuanto a los diferentes potenciales de aprendizaje entre los dos sectores, no es explícitamente considerado para la composición del libro didáctico.

Palabras claves: Aprendizaje. Currículo. Libro Didáctico.

\section{Flávia Eloisa Caimi}

E-mail: caimiribeiro@via-rs.net

\section{Sandra Regina Ferreira de Oliveira}

E-mail: sandraoliveira.uel@gmail.com knowledge progression in the collections studied, what represents a difficult to point the qualitative advances in the last step of basic education. In this way, the sparse mentions to the different learning potentials found in the documents isn't explicitly considered to the preparation of the didactical book.

Keywords: Learning. Curriculum. Didactical book

Enviado em: 18/1/2014

Versão final: 29/3/2014

Aprovado em: 5/4/2014 